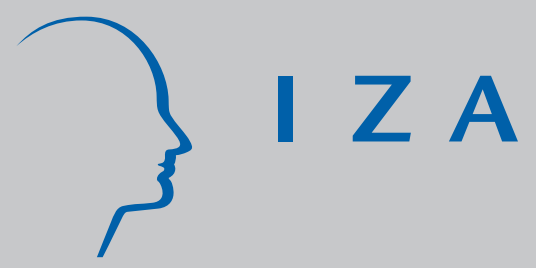

IZA DP No. 943

What Have We Learned About the

Employment Effects of Severance Pay?

Further Iterations of Lazear et al.

J ohn T. Addison

Paulino Teixeira

November 2003 


\title{
What Have We Learned About the Employment Effects of Severance Pay? Further Iterations of Lazear et al.
}

\author{
John T. Addison \\ Paulino Teixeira \\ University of Coimbra and GEMF \\ Discussion Paper No. 943 \\ November 2003 \\ IZA \\ P.O. Box 7240 \\ D-53072 Bonn \\ Germany \\ Tel.: +49-228-3894-0 \\ Fax: +49-228-3894-210 \\ Email: iza@iza.org
}

University of South Carolina and IZA Bonn

This Discussion Paper is issued within the framework of IZA's research area Welfare State and Labor Market. Any opinions expressed here are those of the author(s) and not those of the institute. Research disseminated by IZA may include views on policy, but the institute itself takes no institutional policy positions.

The Institute for the Study of Labor (IZA) in Bonn is a local and virtual international research center and a place of communication between science, politics and business. IZA is an independent, nonprofit limited liability company (Gesellschaft mit beschränkter Haftung) supported by Deutsche Post World Net. The center is associated with the University of Bonn and offers a stimulating research environment through its research networks, research support, and visitors and doctoral programs. IZA engages in (i) original and internationally competitive research in all fields of labor economics, (ii) development of policy concepts, and (iii) dissemination of research results and concepts to the interested public. The current research program deals with (1) mobility and flexibility of labor, (2) internationalization of labor markets, (3) welfare state and labor market, (4) labor markets in transition countries, (5) the future of labor, (6) evaluation of labor market policies and projects and (7) general labor economics.

IZA Discussion Papers often represent preliminary work and are circulated to encourage discussion. Citation of such a paper should account for its provisional character. A revised version may be available on the IZA website (www.iza.org) or directly from the author. 
IZA Discussion Paper No. 943

November 2003

\section{ABSTRACT \\ What Have We Learned About the Employment Effects of Severance Pay? Further Iterations of Lazear et al. ${ }^{*}$}

In this study we examine the contribution of severance pay to employment and unemployment development using data on industrialized OECD countries. Our starting point is Lazear's (1990) empirical dictum that severance payment requirements adversely impact the labor market. We extend his sample period and add to his parsimonious specification a variety of fixed and time-varying labor market institutions. While the positive effect of severance pay on unemployment garners some support, there is no real indication of adverse effects for (the three) other employment outcomes identified here. Moreover, with the possible exception of collective bargaining coordination, the role of institutions is also more muted than suggested in the literature.

JEL Classification: E24, J23, J64, J65

Keywords: severance pay, employment protection, employment, labor force participation, unemployment, long-term unemployment, time-varying labor market institutions

Corresponding author:

John T. Addison

Department of Economics

Moore School of Business

University of South Carolina

1705 College Street

Columbia, SC 29208

USA

Tel.: +1 8037774608

Fax: +1 8037776876

Email: ecceaddi@moore.sc.edu

* This paper was presented at the World Bank/IIASA/ Ludwig Boltzmann Institute for Economic Analysis Workshop on Severance Pay Reform: Toward Unemployment Savings and Retirement Accounts, Laxenberg/Vienna, November 7-8, 2003. 


\section{Introduction}

Refocused by the work of Lazear (1990), analysis of the impact of job security provisions on labor market outcomes was among the most studied topics in labor economics during the decade of the $1990 \mathrm{~s}^{1}$ and, now extending beyond proximate causation, shows every sign of continuing to be a key research theme in the first decade of the new millennium (see, in particular, Botero et al., 2003). Interest in employment protection remains keen because of continuing high unemployment and sluggish growth in much of Europe. But the economics profession has failed to provide consistent results on the consequences of employment protection, as is evidenced by the very pessimistic conclusions of, say, Heckman and Pagés (2000) on the one hand and the guarded optimism of the OECD (1999) on the other.

Although theory can provide the basis for different expectations regarding the effects of employment protection on labor market outcomes, data limitations would seem in this case to have played a more important role than usual in accounting for diversity of finding (on which, see Addison and Teixeira, 2003). The data problems are reflected in models that are parsimonious in both the range of explanatory variables deployed and in the time frame examined. To be sure, in the years following Lazear's pioneering analysis the data situation has improved in terms of refinements to the key independent variable and with the availability of information on new regressors. But data constraints have continued to cast a long shadow over the economic analysis of employment protection. In particular, the needs of wider country coverage and an extended time series have consequences for the number of explanatory variables than can be included in the empirical model. The tradeoffs that have to be made might be expected to encourage more humility on the part of investigators than is apparent in the literature.

The purpose of the present paper is twofold. First, we seek to document the problems arising from the prototypical parsimonious model, using Lazear's famous paper as an organizing device. In updating Addison, Teixeira, and Grosso (2000), we will further discuss the robustness of Lazear's major predictions as to the role of his preferred measure of job security (viz. the no-fault severance pay granted to a blue-collar worker with 10 years service, or $S E V$ ) on various employment indicators. Our sample covers an (extended) interval of more than four decades, namely, from 1956 to 1999. In a new 
departure, we will also address the course of long-term unemployment - and drop the average hours worked measure used by Lazear - albeit for a much shorter period (19791999).

Our second goal is to discuss the sensitivity of the basic employment protection result to a different and more comprehensive measure of job protection (e.g. the OECD composite index of the severity or coerciveness of employment laws) and other labor market institutions. Replacement of the partial indicator $S E V$ by some composite index capturing other seemingly important aspects of the job regulatory framework - such as a measure of procedural delays in dismissals and the permissibility of fixed-term contracts - is expected to improve the explanatory power of the model, although this advantage might be compromised or undercut by a shortened time series. For its part, the failure to include variables such as the degree of collective bargaining coverage or the degree of employee and employer coordination in wage bargaining might be a more serious source of bias in the estimated parameters than the use of such a partial indicator of employment protection.

As a practical matter, most measures of 'labor market institutions' are seldom available in a continuous form. Rather, they are one-off purpose-built constructs or at best only observed at a few points in time. ${ }^{2}$ This reality leaves the researcher with two options: either assume these variables are roughly constant over time and run the model on fixed institutions (in which case the analysis can be extended to cover almost half a century), or instead assume time-varying institutions and trade a presumably more informative set of institutions off against a substantially smaller number of observations (via the reduction in the respective time series). To conduct our 'robustness test' of the parsimonious specification used by Lazear, therefore, we shall follow two routes. First, we use annual data in conjunction with fixed institutions throughout (i.e. from 1956 up to 1999). Second, and this is our preferred route, we average our annual data on (four) labor market performance indicators over 5-year periods and use time-varying institutions for which we have observations at different moments in time (at least three). The sample period in this case is necessarily shorter and covers the period 1970-99 (1979-99 in the case of the long-term unemployment equation). 
Assuming fixed labor market institutions over a period of almost half a century the first route - seems at first glance rather heroic, ${ }^{3}$ but the pooling of cross-section and time-series data offers an indication of the effect of time-varying severance pay over an extended period that is embedded within in a richer institutional context. The second route, by dropping the assumption of fixed institutions, reduces both the sample period and the number of institutions, but eliminates the need for interpolation in order to obtain (artificial) annual time-varying data. This approach, which also allows the researcher to focus on the long-term impact of policy intervention in labor markets, has found some favor in the literature (see Nickell, 1997; Blanchard and Wolfers, 2000; and Bertola, Blau, and Kahn, 2001). Note that our set of time-varying labor institutions and range of labor market performance indicators is wider than has been used in this literature.

\section{Modeling and Data}

\section{Specification}

The sample panel structure of our database allows for a wide range of sensitivity tests. In the most favorable case, we will be able to work with data on 21 OECD countries over 44 consecutive years.

We will begin with the standard Lazear specification containing country specific effects, which can be written:

$$
y_{i t}=c_{i}+\sum_{j} X_{i j t} b_{j}+e_{i t},
$$

where $y$ denotes the labor market outcome, $X$ is the set of explanatory and control variables, and $c$ captures the country specific effect. In the original model, the vector $X$ included severance pay, the proportion of the population that is aged between 25 and 65 , and the growth in GDP per capita. Lazear also adds a quadratic time trend. At this stage, the model assumes away any reverse causation or endogeneity of the explanatory variables - although Lazear (pp. 722-23) subsequently addresses the causality issue by, inter al., regressing changes in severance pay between $t$ and $t+1$ on levels at time $t$ of three of the four dependent variables. In our fitted regressions we will only address directly the problems arising from autocorrelation, where our first-pass solution will be to assume a (common) first-order serially correlated error term. Specifically, this approach 
will be applied in generating Tables 2 through 4 which cover the sample period 1956$1999 .^{4}$

Extending the vector $X$ of explanatory variables in equation (1) to include measures of labor market institutions requires a slight change to the model specification and estimation procedures. In particular, since the inclusion of the additional regressors reduces substantially the length of the panel - especially if the model includes timevarying variables - GLS random effects estimates will be used rather than the standard fixed effects model. Within this framework we will also introduce time dummies to proxy unobserved cross-country (common) shocks. This approach is followed in Tables 5 through 7 , and the general formulation can be described as follows:

$$
y_{i t}=c_{i}+d_{t}+\sum_{j} X_{i j t} b_{j}+e_{i t},
$$

where $t$ denotes the 5 -year periods, $d_{t}$ is the time effect for period $t$, and $X$ now contains the institutional variables.

Our final model extension includes the interaction of labor market institutions and time (i.e. unobserved shocks). The interaction terms are intended to capture the 'product' of shocks and institutions, the presumption being that a particularly unfavourable labor market regulation will impact labor market performance more severely in bad times. In this case, we use a nonlinear specification of the following type:

$$
y_{i t}=c_{i}+d_{t}\left(1+\sum_{j} X_{i j t} b_{j}\right)+e_{i t} .
$$

Our findings using this specification are contained in Table 8, with all variables being expressed in terms of deviations from the sample mean. ${ }^{5}$

\section{Data}

Our database contains observations on a maximum of 21 OECD countries: Austria, Australia, Belgium, Denmark, Finland, France, Germany, Ireland, Italy, Japan, the Netherlands, New Zealand, Norway, Portugal, Spain, Sweden, Switzerland, the United Kingdom, the United States, Greece, and Israel. Information on the country sample, labor market outcomes, and explanatory variables for the period 1956-84 is provided in Addison, Teixeira, and Grosso (2000). For present purposes, we limit our comments to how we updated this information between 1985 and 1999. 
The employment population ratio (EMPPOP), the unemployment rate (UNRATE), and the labor force participation rate $(L F P R)$ were updated using the OECD publication Labor Market Statistics. The same source was used to compute the right hand side variable capturing the share of the population aged 25 to 65 years (WRKAGE) and the long-term unemployment rate (LTUNRATE) (in this case from 1979 to 1999). The growth in GDP per capita (GROWTH) was calculated from the International Financial Statistics Yearbook (2002).

We also updated the severance payment variable (i.e. the statutory entitlement in months of pay due to a blue-collar worker with 10 years of service at termination, separated for reasons unconnected with his/her behaviour), using the detailed information on dismissals procedures for 1992-99 contained in Bertola, Boeri, and Cazes (2000). This material covers only 11 OECD countries - Australia, Austria, Denmark, France, Germany, Ireland, Italy, New Zealand, Spain, the United Kingdom, and the United States. We therefore supplemented it with data for other countries from the OECD Employment Outlook (1999, Table 2.2) which documents the changes in severance pay for no-fault individual dismissals in the 1990s. Using this procedure, it was possible to code the severance payment variable after 1992 for all countries other than Greece and Israel.

(Table 1 near here)

To set our severance pay measure in wider relief, we also obtained data on the severance pay due to a 40 year-old white-collar employee made redundant after 10 years of service. These two indicators were then converted into rankings (in ascending order of stringency) and are reported in columns (1) and (2) of Table 1. Column (3) of this table also gives the country ranking order derived from Heckman and Pagé's (2000) cardinal measure of firing costs (which controls for the entire tenure-severance pay profile), while in columns (4) through (8) we introduce some other widely used indices of stringency of employment protection laws, including the employment protection index used by Nickell (1977). Finally, columns (9) and (10) of the table present the corresponding country rankings of more narrowly defined indices of industrial relations and social security laws, respectively. 
As shown by the Spearman ranking correlation at the foot of Table 1, the three measures of severance pay in columns (1) to (3) are, as expected, highly correlated but the correlation of severance pay with the broad employment protection indicators in columns (4) through (8) offers a less consistent pattern. And the correlations between severance pay and the indicators of industrial relations and social security are extremely low. For their part, the broader indicators of the stringency of employment protection laws are strongly correlated: the correlation coefficients between the column (5) measure - OECD, late 1990s - and columns (4), (6), (7), and (8) are all statistically significant at the .01 level. There is, however, no correlation between the OECD measure and the index of social security reported by Botero et al. in column (10).

Finally, six labor market institutions are identified in the present treatment. These are the unemployment insurance replacement rate (UIRR); the maximum duration of unemployment benefits $(M D U B)$; expenditure on active labor market policy $(A L M P)$; union density (UDEN); collective bargaining coverage (UCOV); overall employee and employer coordination in wage bargaining (TCOOR); and the tax wedge (TXWEDGE). As mentioned above, since none of these series is available on a yearly basis, we constructed 5-year averages (1970-99) using the interpolations described in Appendix Table 1. Data sources and variable definitions are also included in this table, as well as Nickell's (1997) time-invariant employment protection index.

\section{Findings}

As noted earlier, Lazear's pioneering study acted as the catalyst for more intensive and systematic study of the effects of job security provisions on labor market performance. After more than a decade since its publication, the Lazear argument that severance pay reduces employment and elevates joblessness (in imperfectly competitive markets) not only remains a mainstay of orthodoxy but also continues to attract broad empirical support (see the survey by Addison and Teixeira, 2003). In what follows while we do not claim to detect any evidence suggesting pro-employment effects of stringent labor regulation, we will nonetheless contend that the more flamboyant empirical findings in the spirit of Lazear need to be interpreted with caution. 
To begin with, we take Lazear's parsimonious model and re-estimate it using an additional 15 years of data. Next, in recognition that much data on labor market institutions has only become available in recent years, we test the robustness of the original model to the inclusion of an extended set of such explanatory variables, and in the process address some more contemporary issues. To repeat, in this stage of our empirical analysis we shall look at the effects of severance pay on unemployment and employment for a longer sample period than does Lazear (as previously noted, the exception is the long-term unemployment outcome measure that we substitute for Lazear's working time indicator and for which we have a shorter run of data), and in a framework that accommodates time-varying labor market institutions.

(Table 2 near here)

Table 2 shows the results of applying the most restrictive version of the Lazear model, namely, estimation of the effects of severance pay (inter al.) on labor market outcomes using pooled cross-section time-series data with no country dummies. As in Addison, Teixeira, and Grosso (2000, Table 2), the results of this specification are broadly supportive of Lazear's empirical proposition that job protection, proxied by the SEV variable, adversely impacts employment, labor force participation, and overall unemployment. (Also consistent with Lazear is the statistical insignificance of the GROWTH.SEV interaction and the well-determined effects of the population control $W R K A G E$.) Using a shorter time-series, it also appears that the association between SEV and long-term unemployment, LTUNRATE, is negative and well determined (column 3).

(Table 3 near here)

Since there no obvious reason to neglect national idiosyncracies, Table 3 shows the effect of introducing country fixed effects. Robustness is clearly an issue. The introduction of country dummies renders the coefficient estimates of $S E V$ statistically insignificant in both the EMPPOP and LTUNRATE regressions. The association between SEV and UNRATE remains positive and well determined while there is a sign reversal in the case of LFPR. The absence of country fixed effects is statistically rejected in all regressions at the .01 level.

(Table 4 near here) 
We also tested for the presence of autocorrelation. Table 4 gives the results of fitting the fixed effects model assuming a first-order autocorrelation term. It can be seen that the null of no serial (first-order) correlation is clearly rejected. As it is apparent, the re-estimation takes no prisoners: none of the coefficient estimates for $S E V$ is any longer statistically significant at conventional levels.

At this point we are of course reminded of the parsimonious nature of the Lazear model. This is next issue to be tackled. But thus far at least we would conclude that the Lazear model has failed to pass muster. This conclusion is also reached by Addison, Teixeira, and Grosso (2000). The difference here is that we are updating the database with information for more recent years that, with the uptick of unemployment, might perhaps have been expected to offer a more promising milieu for the model.

The parsimony of Lazear's specification has been addressed in various ways in the subsequent literature. But one amendment has proved increasingly popular, namely, the class of models whose general specification is described in equation (2) above. Their distinctive feature is the introduction of time-varying measures of labor market institutions, on the one hand, and time dummies as proxies of unobservable shocks, on the other. One of the first authors to apply this specification was Nickell (1997) who combined two-time periods - 6-year averages of data for 1983-88 and 1989-94 - with a wide set of explanatory variables.

\section{(Table 5 near here)}

We begin with a quasi-replication of Nickell's (1997) approach in Table 5. In this exercise the left hand side variables are again extracted from our own database, whereas the right hand side variables are taken from Nickell. The surprising result is the statistical insignificance of most of the parameter estimates. But there is some support for Lazear's findings: the higher the $E P L$ ranking (i.e. the more generous employment protection), the lower the employment population ratio and labor force participation. Moreover, the longterm unemployment rate - but not overall unemployment - is also impacted unfavourably by employment protection legislation. Appendix Table 2 reports a somewhat different exercise in which both the right-hand side and left-hand side variables are taken from our own database, with the exception of ALMP and benefit duration. There is obvious 
corroboration of the findings in Table 5. Taken together, these results suggest that quasicross-section data (two data points spanning two decades) if they do not make a strong case for labor market institutions do offer a measure of support for Lazear.

Tables 6 and 7 show the more interesting case in which the number of data points has been enlarged. But this extension is not achieved without cost. Thus, in Table 6, we have a maximum of nine periods covering the entire sample period 1956-99 and seven fixed labor market institutional variables (the replacement rate, benefit duration, ALMP, union density, union coverage, union and employer coordination, and the tax wedge) plus the severance pay variable. In Table 7 the sample period is 1970-99, but we have a smaller number of labor market institutions which are now time varying. The Nickell study considered eight institutional variables of which one is time-invariant $(E P L)$.

(Tables 6 and 7 near here)

Clearly, these innovations produce an improvement in the precision of the institutional variables in the case of UNRATE (in both tables). For the other regressions (EMPPOP, LTUNRATE, and LFPR), the coefficient estimates are statistically significant in just 6 out of 24 cases in Table 6 and in only 3 out 18 cases in Table 7. But the SEV coefficient is now well determined only in 3 out of 8 regressions (taking Tables 6 and 7 together), while in Table 5 and the Appendix Table 2 it was well determined in 6 out of 8 cases.

We should also report the results from a different exercise using annual data (1956-99) in which we added seven fixed institutional variables (including the tax wedge) to the full set of original Lazear regressors. ${ }^{6}$ In this procedure 14 out of 32 (i.e. $8 \times 4$ ) coefficients estimates were found to be statistically significant, which is a slight improvement over Table 6, for example, where 11 such estimates were well determined. In particular, the $S E V$ variable was positively signed and statistically significant in the UNRATE and LTUNRATE equations (albeit only at the .10 level in the latter). Bearing in mind the results from Table 4 above, it can be seen that the $S E V$ coefficient estimate does show some sensitivity to the inclusion of labor market institutions. Based on the same type of augmented-Lazear specification we then made an attempt to determine the degree of sensitivity of the severance pay coefficient in Table 4 to the introduction of all possible combinations of institutional variables (viz. the seven fixed measures mentioned above). 
From this exercise it emerged that the $S E V$ coefficient estimate was never statistically significant in the EMPPOP regression, but was always positive and well determined in the in the UNRATE regression. The 'addition' of the institutional covariates to the LTUNRATE regression yielded a marginally statistically significant coefficient estimate for $S E V$ in roughly 50 percent of the cases, while in the $L F P R$ equation the estimate was statistically significant (although on this occasion at both the 0.05 and 0.10 levels) in approximately two-thirds of all cases. In sum, while the sensitivity of the $S E V$ coefficient in the EMPPOP equation seems to be low, in the other three cases - UNRATE, LFPR and LTUNRATE - sensitivity to model specification cannot be ignored. Nonetheless, the consequences for standard Lazear equations of ignoring labor market institutions are arguably less severe than might be expected, although a more definite conclusion necessarily awaits the provision of better (i.e. annual) data on institutions.

We should also note that we experimented with alternative measures of employment protection legislation in substitution for $S E V$ and Nickell's (1997) EPL index. But the broad picture is unchanged: the role of institutions is less 'active' than one might expect. Our finding that institutions seem to be of greater importance in explaining overall unemployment than the other indicators is also worthy of note. To some degree, it parts company with the notion that the impact of labor regulations on unemployment is more ambiguous than its effects on employment.

These remarks bring us finally to model (3). In this model, it is hypothesized that labor institutions only reveal their true 'color' in conjunction with adverse economic conditions (e.g. negative shocks). Accordingly, if a given country is 'endowed' with a non-employment friendly set of labor laws, the unfavourable impact of the latter may not surface if that nation fails to experience hard times. The non-linear specification of equation (3) is particularly suited to address the interaction between (observed or unobserved) shocks and institutions.

In fitting this model to the data we again consider the sample period 1970-99 and the same 5-year averages as before. The set of time-varying institutions is also the same; in particular, we retain $S E V$ variable as our indicator of employment protection. In other words, we are implementing here the 'work-in-progress' part of Blanchard and Wolfers' (2002, p. C23) analysis, that is to say, a model in which all institutional regressors are 
allowed to vary over time. We note that Blanchard and Wolfers attempted to run the model with time-varying institutions, but only in a limited way, using just the employment protection and unemployment insurance covariates. Blanchard and Wolfers also focus exclusively on the course of unemployment, and so do not consider the LTUNRATE, LFPR, and EMPPOP outcome indicators considered here. (Bertola, Blau, and Kahn, 2001, likewise concentrate on unemployment developments.) Finally, observe that although data on observable shocks is available we restrict our attention to the case of unobservable shocks which we proxy with time dummies.

(Table 8 near here)

The results of this analysis are presented in Table 8 . In only 7 out of 24 cases are the labor market institutional parameters estimated with precision. The $S E V$ variable is statistically significant in just the UNRATE equation, while UCOV and TCOOR are never statistically significant. Most surprisingly, developments in long-term unemployment are almost solely explained by country and time effects, with no role reserved for labor market institutions. We note parenthetically that the restricted version of model (3) - that is, the model in which $X_{i j}$ is time invariant - fully replicates Blanchard and Wolfers findings for unemployment (e.g. their Table 1), with all variables being identically signed and statistically significant (the active labor market policy and union density covariates are not statistically significant). Applying the same model to the EMPPOP, LFPR, and LTUNRATE outcomes revealed approximately the same pattern as described in Table 8. In the case of the long-term unemployment regression, none of the coefficient estimates is statistically significant. What these results show is the seemingly inability of labor market institutions as a whole to materially impact labor market outcomes under the more realistic scenario of time-varying indicators. The $S E V$ variable, with the exception of the unemployment case, does not seem to play any particularly prominent role either. The attenuated role of collective bargaining coordination is further weakened.

\section{Conclusions}

The effects of job security provisions on job turnover (i.e. job creation and job destruction) and on unemployment flows are fairly well established. Net effects are less firmly established, despite widespread acceptance of the view that stronger employment 
protection will entail lower employment and higher unemployment. In the present treatment we have offered a wide-ranging combination of empirical strategies in which the effects of institutions on labor market aggregates are analyzed across a variety of sample periods, explanatory variables, and estimation techniques.

Our starting point was the influential Lazear study of the role of severance pay in influencing employment and joblessness. By adding more regressors - specifically, labor market institutions - to the original Lazear model, we found little slippage of the unemployment result. Much weaker was the evidence linking severance pay to the rate of long-term unemployment and to the employment population ratio and the labor force participation rate. Surprisingly, in virtually all model specifications, and irrespective of the empirical strategy used, we found low statistical significance of the other institutional variables. Even the performance of the union and employer coordination variables, often viewed as favorable to labor market development, was not impressive overall.

We cannot of course conclude from the foregoing exercise that labor market institutions - and job protection in particular - do not matter. Rather, our findings indicate that we simply do not yet know enough about the role of such institutions, or, expressed differently, that the extent of their adverse impact on the labor market is not easily gauged. For instance, we cannot exclude the possibility that different combinations of labor institutions and regulations may produce quite similar outcomes. It may even be the case that the quest for improved labor market performance is better directed elsewhere, although we would resist this interpretation, arguing that lingering uncertainty as to the impact of the institutions identified here is an inescapable consequence of the vintage of research in this area. 


\section{Endnotes}

1. For the flavor of the earlier literature, see Buechtemann (1993).

2. This raises the specter of research Darwinism, alluded to by Blanchard and Wolfers (2000, p. C22)

3. Assuming fixed labor market institutions over a period of almost half a century seems rather heroic, but with the exceptions of Portugal (in 1974) and Spain and Greece (1975 and 1973, respectively), it might be argued that none of the balance of our sample - apart from 1979-1990 Britain under Mrs. Thatcher - has experienced dramatic political changes.

4. Addison, Teixeira, and Grosso (2000) discuss the problems arising from a panel specification such as equation (1).

5. In this case, the difference between the coefficient estimate for the first time dummy and the last time dummy gives the change in $y_{i t}$ due to exogenous shocks (if $X_{i t}=\bar{X}$, then $\hat{y}_{i t}=\hat{c}_{i}+\hat{d}_{t}$ ). We do not discuss the case of observable shocks.

6. This exercise was carried out using the GLS random effects model to allow the presence of time-invariant regressors. 


\section{References}

Addison, John T. and Paulino Teixeira. "The Economics of Employment Protection." Journal of Labor Research 25 (Winter 2003): 85-129.

Addison, John T., Paulino Teixeira, and Jean-Luc Grosso. "The Effect of Dismissals Protection on Employment: More on a Vexed Theme." Southern Economic Journal 67 (July 2000): 105-122.

Bertola, Giuseppe, Tito Boeri, and Sandrine Cazes. "Employment Protection and Labour Market Adjustment in some OECD Countries: Evolving Institutions and Variable Enforcement.” Employment and Training Papers 48, ILO, 1999.

Bertola, Giuseppe, Francine Blau, and Lawrence M. Kahn. "Comparative Analysis of Labor Market Outcomes: Lessons from International Long-Run Evidence.” In A. Krieger and R. Solow, eds., Sustainable Employment. New York: Century and Russell Sage Foundations, 2001.

Blanchard, Olivier and Justin Wolfers. "The Role of Shocks and Institutions in the Rise of European Unemployment: The Aggregate Evidence.” Economic Journal 110 (March 2000): C1-C33.

Botero, Juan, Someon Djankov, Rafael La Porta, Florencio Lopez-de-Silanes, and Andrei Schliefer. "The Regulation of Labor." NBER Working Paper 9756. Cambridge, MA: National Bureau of Economic Research, June 2003.

Buechtemann, Christoph F. "Introduction: Employment Security and Labor Markets." In Christoph F. Buechtemann, ed., Employment Security and Labor Market Behavior Interdiscliplinary Approaches and International Evidence. Ithaca, NY: ILR Press, pp.366, 1993.

Di Tella, Rafael and Robert MacCulloch. "The Consequences of Labor Market Flexibility: Panel Evidence Based on Survey Data." Unpublished paper. Harvard Business School, April 1999.

Heckman, James J. and Carmen Pagés. "The Cost of Job Security Regulation: Evidence from Latin American Countries.” NBER Working Paper 7773. Cambridge, MA: National Buereau of economic Research, 2000.

IMF. International Financial Statistics Yearbook. Washington: International Monetary Fund, 2002.

Lazear, Edward P. "Job Security Provisions and Employment." Quarterly Journal of Economics 105 (August 1990): 699-726. 
Mercer Human Resource Consulting. European Employment Conditions. Mimeo. London, 2003.

Nickell, Stephen. "Unemployment and Labor Market Rigidities: Europe versus North America." Journal of Economic Perspectives 11 (Summer 1997): 55-74.

OECD. "Employment Protection and Labor Market Performance." Employment Outlook (June 1999): 49-132.

OECD. The OECD Jobs Strategy, Making Work Pay: Taxation, Benefits, Employment and Unemployment. Paris: OECD, 1997.

OECD. "Economic Performance and the Structure of Collective Bargaining." Employment Outlook (July 1997): 63-92.

OECD. The OECD Jobs Study, Evidence and Explanations, Part II: The Adjustment Potential of the Labor Market. Paris: OECD, 1994.

OECD. The OECD Labor Market Statistics. Paris: OECD. 


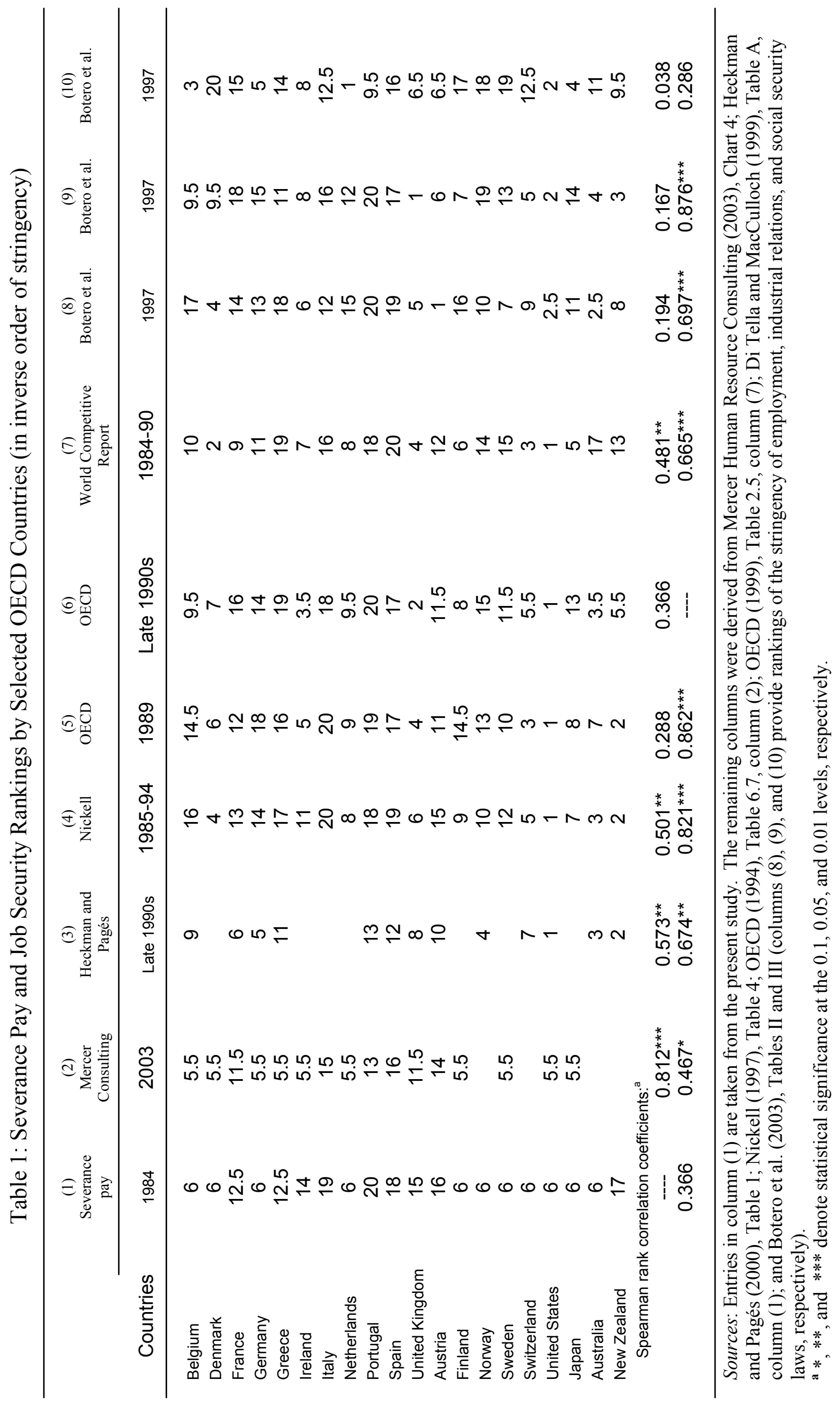


TABLE 2

Pooled Estimations - No Country Dummies (1956-99)

\begin{tabular}{lllll}
\hline \multirow{2}{*}{ Independent variable } & \multicolumn{4}{c}{ Dependent variable } \\
\cline { 2 - 5 } & & \multicolumn{5}{c}{ LMPPOP } & UNRATE & LTUNRATE & LFPR \\
\hline Intercept & -0.1305 & 0.1129 & -0.1372 & -0.1080 \\
& $(0.0393)$ & $(0.0276)$ & $(0.3414)$ & $(0.0349)$ \\
SEV & -0.0064 & 0.0032 & 0.0243 & -0.0055 \\
& $(0.0007)$ & $(0.0005)$ & $(0.0045)$ & $(0.0007)$ \\
GROWTH & -0.1200 & -0.0024 & 1.5883 & -0.1320 \\
& $(0.0718)$ & $(0.0504)$ & $(0.4882)$ & $(0.0638)$ \\
GROWTH.SEV & 0.0097 & -0.0005 & 0.0445 & 0.0118 \\
& $(0.0180)$ & $(0.0126)$ & $(0.1471)$ & $(0.0160)$ \\
WRKAGE & 0.8703 & -0.1582 & -1.2188 & 0.8438 \\
& $(0.0614)$ & $(0.0431)$ & $(0.3117)$ & $(0.0546)$ \\
$\mathrm{N}$ & 833 & 832 & 348 & 833 \\
$\mathrm{~F}(\mathrm{k}, \mathrm{N}-(\mathrm{k}+1))$ & 72.5 & 83.9 & 23.7 & 108.1 \\
$\mathrm{R}^{2}$ & 0.35 & 0.38 & 0.29 & 0.44 \\
& & & & \\
\hline
\end{tabular}

Standard errors are given in parentheses.

Note: The regression includes YEAR and YEAR ${ }^{2}$ terms. The LTUNRATE series only begins in 1979. $\mathrm{N}$ denotes the number of countries multiplied by the number of observations per country. 
TABLE 3

Fixed Effects Regressions (1956-99)

\begin{tabular}{lllll}
\hline \multirow{2}{*}{ Independent variable } & \multicolumn{4}{c}{ Dependent variable } \\
\cline { 2 - 5 } & EMPPOP & UNRATE & LTUNRATE & LFPR \\
\hline SEV & 0.0005 & 0.0017 & 0.0084 & 0.0011 \\
& $(0.0005)$ & $(0.0005)$ & $(0.0071)$ & $(0.0005)$ \\
GROWTH & 0.0089 & -0.0668 & 1.5776 & -0.0237 \\
& $(0.0368)$ & $(0.0360)$ & $(0.2114)$ & $(0.0327)$ \\
GROWTH.SEV & -0.0008 & 0.0064 & 0.0444 & 0.0033 \\
& $(0.0088)$ & $(0.0086)$ & $(0.0630)$ & $(0.0078)$ \\
WRKAGE & 0.5724 & 0.0875 & -0.2573 & 0.6356 \\
& $(0.0422)$ & $(0.0412)$ & $(0.2180)$ & $(0.0374)$ \\
$\mathrm{N}$ & 833 & 832 & 348 & 833 \\
$\mathrm{~F}(\mathrm{k}, \mathrm{N}-(\mathrm{k}+1))$ & 67.3 & 121.1 & 44.0 & 199.9 \\
$\mathrm{R}^{2}$ & 0.83 & 0.65 & 0.23 & 0.83 \\
\hline
\end{tabular}

Standard errors are given in parentheses.

Note: The regression includes a constant plus YEAR and YEAR ${ }^{2}$ terms. The LTUNRATE series only begins in 1979 . The null hypothesis that the country fixed effects are jointly equal to zero is rejected in all cases. 
TABLE 4

Fixed Effects Regressions with Correction for Autocorrelation (1956-99)

Independent variable

Dependent variable

\begin{tabular}{lccll} 
& & & & \\
& EMPPOP & UNRATE & LTUNRATE & LFPR \\
\hline SEV & -0.00052 & 0.00085 & 0.0043 & -0.00022 \\
& $(0.00046)$ & $(0.00054)$ & $(0.0073)$ & $(0.00040)$ \\
GROWTH & -0.00039 & -0.02576 & 0.9240 & -0.01235 \\
& $(0.01220)$ & $(0.01461)$ & $(0.1391)$ & $(0.01064)$ \\
GROWTH.SEV & 0.00318 & 0.00295 & 0.1003 & 0.00498 \\
& $(0.00268)$ & $(0.00320)$ & $(0.0432)$ & $(0.00233)$ \\
WRKAGE & 0.25701 & 0.03743 & -0.0018 & 0.30429 \\
& $(0.05260)$ & $(0.06009)$ & $(0.2720)$ & $(0.04604)$ \\
$\mathrm{N}$ & 812 & 811 & 329 & 812 \\
$\mathrm{~F}(\mathrm{k}, \mathrm{N}-(\mathrm{k}+1))$ & 10.7 & 10.1 & 13.4 & 20.5 \\
\hline
\end{tabular}

Standard errors are given in parentheses.

Notes: The regression includes a constant plus YEAR and YEAR ${ }^{2}$ terms. The LTUNRATE series only begins in 1979 . The null hypothesis that the country fixed effects are jointly equal to zero is rejected in all cases. The null hypothesis that the error term is not first-order autoregressive is also rejected. 
Random Effects (GLS) Regressions with Eight Labor Market Institutions and Two Data Points (6-year averages, 1983-88 and 1989-94)

Independent variable

Dependent variable

\begin{tabular}{lllll}
\cline { 2 - 4 } & & & & \\
& EMPPOP & UNRATE & LTUNRATE & LFPR \\
\hline Employment protection (1-19) & -0.0055 & 0.0015 & 0.0216 & -0.0055 \\
& $(0.0025)$ & $(0.0020)$ & $(0.0063)$ & $(0.0019)$ \\
Replacement rate (\%) & 0.0008 & -0.0002 & -0.0010 & 0.0005 \\
& $(0.0005)$ & $(0.0004)$ & $(0.0014)$ & $(0.0004)$ \\
Benefit duration (years) & -0.0070 & 0.0051 & 0.0264 & -0.0063 \\
& $(0.0059)$ & $(0.0054)$ & $(0.0176)$ & $(0.0045)$ \\
ALMP (\%) & -0.0003 & 0.00004 & -0.0004 & -0.0002 \\
& $(0.0002)$ & $(0.0002)$ & $(0.0007)$ & $(0.0002)$ \\
Union density (\%) & 0.0003 & -0.0001 & 0.0008 & 0.0003 \\
& $(0.0007)$ & $(0.0005)$ & $(0.0017)$ & $(0.0005)$ \\
Union coverage (1-3) & -0.0144 & 0.0287 & 0.0549 & -0.0041 \\
& $(0.0204)$ & $(0.0194)$ & $(0.0580)$ & $(0.0158)$ \\
Union and employer & 0.0134 & -0.0153 & -0.0510 & 0.0129 \\
coordination (2-6) & $(0.0093)$ & $(0.0081)$ & $(0.0287)$ & $(0.0071)$ \\
Tax wedge (\%) & -0.0001 & 0.0004 & -0.0018 & -0.0002 \\
$\mathrm{R}^{2}$ & $(0.0012)$ & $(0.0009)$ & $(0.0028)$ & $(0.0009)$ \\
Wald $\chi^{2}$ & 0.68 & 0.55 & 0.75 & 0.74 \\
$\mathrm{~N}$ & 25.1 & 16.1 & 40.6 & 36.47 \\
\hline & 38 & 38 & 34 & 38 \\
\hline
\end{tabular}

Standard errors are given in parentheses.

Notes: The model includes a constant term and a time dummy representing the 1989-94 period. All explanatory variables are taken from Nickell (1997) while the dependent variables are from our own dataset. The results are virtually unchanged when the dependent variables are expressed in logs. 
TABLE 6

Random Effects (GLS) Regressions with Eight Labor Market Institutions and Nine Data Points (5-year averages, 1956-99)

Independent variable

Dependent variable

\begin{tabular}{|c|c|c|c|c|}
\hline & ЕМРPOP & UNRATE & LTUNRATE & $L F P R$ \\
\hline$S E V$ (months) & $\begin{array}{c}0.0004 \\
(0.0013)\end{array}$ & $\begin{array}{c}0.0017 \\
(0.0010)\end{array}$ & $\begin{array}{c}0.0046 \\
(0.0110)\end{array}$ & $\begin{array}{c}0.0010 \\
(0.0012)\end{array}$ \\
\hline Replacement rate (\%) & $\begin{array}{l}-0.0002 \\
(0.0006)\end{array}$ & $\begin{array}{c}0.0007 \\
(0.0003)\end{array}$ & $\begin{array}{c}0.0017 \\
(0.0023)\end{array}$ & $\begin{array}{c}0.00002 \\
(0.00059)\end{array}$ \\
\hline Benefit duration (years) & $\begin{array}{c}0.0008 \\
(0.0078)\end{array}$ & $\begin{array}{l}-0.0019 \\
(0.0040)\end{array}$ & $\begin{array}{l}-0.0164 \\
(0.0289)\end{array}$ & $\begin{array}{c}0.0003 \\
(0.0072)\end{array}$ \\
\hline$A L M P(\%)$ & $\begin{array}{l}-0.0012 \\
(0.0011)\end{array}$ & $\begin{array}{c}0.0008 \\
(0.0006)\end{array}$ & $\begin{array}{c}0.0031 \\
(0.0038)\end{array}$ & $\begin{array}{l}-0.0008 \\
(0.0010)\end{array}$ \\
\hline Union density (\%) & $\begin{array}{c}0.0002 \\
(0.0007)\end{array}$ & $\begin{array}{c}0.0004 \\
(0.0004)\end{array}$ & $\begin{array}{c}0.00002 \\
(0.00243)\end{array}$ & $\begin{array}{c}0.0004 \\
(0.0007)\end{array}$ \\
\hline Union coverage (1-3) & $\begin{array}{l}-0.0557 \\
(0.0220)\end{array}$ & $\begin{array}{c}0.0264 \\
(0.0114)\end{array}$ & $\begin{array}{c}0.2543 \\
(0.0842)\end{array}$ & $\begin{array}{l}-0.0481 \\
(0.0203)\end{array}$ \\
\hline $\begin{array}{l}\text { Union and employer } \\
\text { coordination }(2-6)\end{array}$ & $\begin{array}{l}-0.0301 \\
(0.0120)\end{array}$ & $\begin{array}{c}0.0246 \\
(0.0061)\end{array}$ & $\begin{array}{c}0.1017 \\
(0.0420)\end{array}$ & $\begin{array}{l}-0.0218 \\
(0.0111)\end{array}$ \\
\hline Tax wedge (\%) & $\begin{array}{l}-0.0016 \\
(0.0011)\end{array}$ & $\begin{array}{c}0.0013 \\
(0.0005)\end{array}$ & $\begin{array}{c}0.0033 \\
(0.0037)\end{array}$ & $\begin{array}{l}-0.0010 \\
(0.0010)\end{array}$ \\
\hline $\mathrm{R}^{2}$ & 0.55 & 0.68 & 0.68 & 0.56 \\
\hline Wald $\chi^{2}$ & 54.3 & 267.2 & 176.2 & 155.3 \\
\hline $\mathrm{N}$ (countries, years) & 162 & 162 & 71 & 162 \\
\hline
\end{tabular}

Standard errors are given in parentheses.

Notes: The model includes a constant term and year dummies. ALMP and Union and employer coordination are set to negative. All right hand side variables are taken from Blanchard and Wolfers (2002) with the exception of the SEV variable. (See description in the Appendix Table 1.) 
TABLE 7

Random Effects (GLS) Regressions with Six Time-Varying Labor Market Institutions and Six Data Points (5-year averages, 1970-99). (No interaction between institutions and unobservable shocks.)

Independent variable

Dependent variable

\begin{tabular}{lllll} 
& & & & \\
& EMPPOP & UNRATE & LTUNRATE & LFPR \\
\hline SEV & -0.0019 & 0.0031 & 0.0202 & -0.0007 \\
& $(0.0018)$ & $(0.0014)$ & $(0.0118)$ & $(0.0014)$ \\
Replacement rate (\%) & 0.0003 & 0.0003 & 0.0007 & 0.0005 \\
& $(0.0004)$ & $(0.0003)$ & $(0.0021)$ & $(0.0003)$ \\
Union density (\%) & 0.0002 & -0.0004 & -0.0006 & -0.0001 \\
& $(0.0003)$ & $(0.0002)$ & $(0.0013)$ & $(0.0003)$ \\
Union coverage (1-3) & -0.2430 & 0.0157 & 0.0675 & -0.0170 \\
& $(0.0132)$ & $(0.0085)$ & $(0.0493)$ & $(0.0114)$ \\
Union and employer & -0.0171 & 0.0137 & 0.0090 & -0.0098 \\
coordination (1-3) & $(0.0124)$ & $(0.0079)$ & $(0.0424)$ & $(0.0107)$ \\
Tax wedge (\%) & -0.0004 & 0.00006 & 0.0011 & -0.0004 \\
& $(0.0007)$ & $(0.0005)$ & $(0.0028)$ & $(0.0007)$ \\
$\mathrm{R}^{2}$ & & & & 0.19 \\
Wald $\chi^{2}$ & 0.31 & 0.55 & 0.50 & 92.6 \\
$\mathrm{~N}$ & 22.7 & 88.0 & 119.9 & 92 \\
\hline
\end{tabular}

Standard errors are given in parentheses.

Notes: The model includes a constant term and year dummies. Union and employer coordination are set to negative. All right hand side variables were extracted from our own database. (See description in Appendix Table 1.) 
TABLE 8

Nonlinear Least Squares Regressions with Six Time-Varying Labor Market Institutions and Six Data Points, with Interaction between Institutions and Unobservable Shocks (5-year averages, 1970-99)

Independent variable

Dependent variable

\begin{tabular}{lllll} 
& & & & \\
& EMPPOP & UNRATE & LTUNRATE & LFPR \\
\hline SEV (months) & -0.00005 & 0.1755 & 0.0739 & 0.00007 \\
& $(0.0003)$ & $(0.0843)$ & $(0.1042)$ & $(0.0002)$ \\
Replacement rate (\%) & 0.00008 & 0.0358 & -0.0313 & 0.0009 \\
& $(0.00006)$ & $(0.0132)$ & $(0.0195)$ & $(0.0004)$ \\
Union density (\%) & -0.0002 & -0.0052 & -0.0211 & -0.0002 \\
& $(0.00006)$ & $(0.0076)$ & $(0.0134)$ & $(0.00004)$ \\
Union coverage (1-3) & 0.0003 & 0.1651 & 0.4720 & 0.00007 \\
& $(0.0026)$ & $(0.2372)$ & $(0.3995)$ & $(0.0019)$ \\
Union and employer & 0.000004 & 0.0067 & -0.5170 & 0.00037 \\
coordination $(1-3)$ & $(0.002)$ & $(0.2284)$ & $(0.4062)$ & $(0.0017)$ \\
& & & & \\
Tax wedge $(\%)$ & -0.0004 & -0.0052 & 0.0283 & -0.0003 \\
$\mathrm{R}^{2}$ & $(0.0002)$ & $(0.0138)$ & $(0.0252)$ & $(0.0001)$ \\
& 0.90 & 0.83 & 0.94 & 0.93 \\
$\mathrm{~F}$ & & 11.0 & 21.9 & 32 \\
$\mathrm{~N}$ & 22.3 & 92 & 62 & 92 \\
\hline
\end{tabular}

Standard errors are given in parentheses.

Notes: The model specification is given in equation (3). All right hand side variables were extracted from our database. (See Appendix Table 1.) 


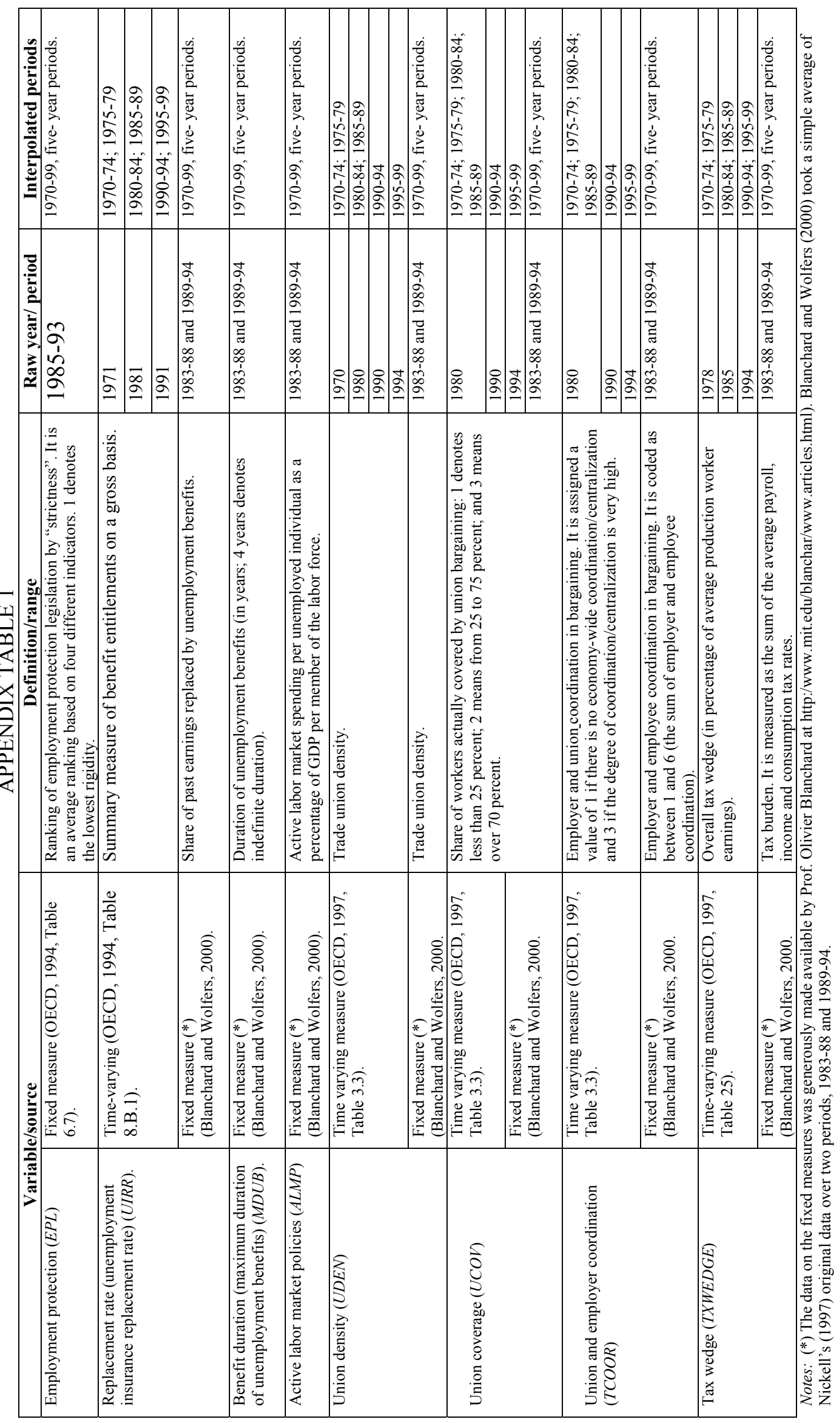




\section{APPENDIX TABLE 2}

Random Effects (GLS) Regressions with Eight Labor Market Institutions and Two Data Points (6-year averages, 1983-88 and 1989-94)

Independent variable

Dependent variable

\begin{tabular}{lllll} 
& & & & \\
& EMPPOP & UNRATE & LTUNRATE & LFPR \\
\hline Severance pay (months) & -0.0077 & 0.0044 & 0.0442 & -0.0076 \\
& $(0.0037)$ & $(0.0031)$ & $(0.0140)$ & $(0.0033)$ \\
Replacement rate (\%) & -0.0010 & 0.0009 & 0.0050 & -0.0008 \\
& $(0.0010)$ & $(0.0008)$ & $(0.0037)$ & $(0.0009)$ \\
Benefit duration (years) & -0.0008 & 0.0022 & 0.0323 & -0.0020 \\
& $(0.0075)$ & $(0.0067)$ & $(0.0200)$ & $(0.0060)$ \\
ALMP (\%) & -0.0004 & 0.0001 & 0.0004 & -0.0004 \\
& $(0.0003)$ & $(0.0003)$ & $(0.0007)$ & $(0.0002)$ \\
Union density (\%) & 0.0015 & -0.0007 & 0.0001 & 0.0011 \\
& $(0.0005)$ & $(0.0004)$ & $(0.0017)$ & $(0.0004)$ \\
Union coverage (1-3) & -0.0008 & 0.0006 & -0.0002 & -0.0004 \\
& $(0.0007)$ & $(0.0006)$ & $(0.0020)$ & $(0.0006)$ \\
Union and employer & 0.0150 & -0.0200 & 0.0683 & 0.0017 \\
coordination (2-6) & $(0.0181)$ & $(0.0156)$ & $(0.0630)$ & $(0.0156)$ \\
Tax wedge (\%) & & & & \\
& 0.0000 & -0.0001 & -0.0022 & -0.0001 \\
$\mathrm{R}^{2}$ & $(0.0011)$ & $(0.0009)$ & $(0.0035)$ & $(0.0009)$ \\
Wald $\chi^{2}$ & & & & \\
$\mathrm{~N}$ & 0.69 & 0.53 & 0.42 & 0.63 \\
\hline
\end{tabular}

Standard errors are given in parentheses.

Notes: The model includes a constant term and a time dummy representing the 1989-94 period. All right hand side variables except ALMP and benefit duration are extracted from our database. (See Appendix Table 1.) 


\section{IZA Discussion Papers}

\begin{tabular}{|c|c|c|c|c|}
\hline No. & Author(s) & Title & Area & Date \\
\hline 929 & $\begin{array}{l}\text { Z. Eckstein } \\
\text { G. J. van den Berg }\end{array}$ & Empirical Labor Search: A Survey & 1 & $11 / 03$ \\
\hline 930 & $\begin{array}{l}\text { M. Lindeboom } \\
\text { F. Portrait } \\
\text { G. J. van den Berg }\end{array}$ & $\begin{array}{l}\text { Individual Mortality and Macro Economic } \\
\text { Conditions from Birth to Death }\end{array}$ & 3 & $11 / 03$ \\
\hline 931 & P. Kooreman & $\begin{array}{l}\text { Time, Money, Peers, and Parents: Some Data } \\
\text { and Theories on Teenage Behavior }\end{array}$ & 5 & $11 / 03$ \\
\hline 932 & $\begin{array}{l}\text { H. N. Mocan } \\
\text { E. Tekin }\end{array}$ & $\begin{array}{l}\text { Guns, Drugs and Juvenile Crime: Evidence from } \\
\text { a Panel of Siblings and Twins }\end{array}$ & 3 & $11 / 03$ \\
\hline 933 & $\begin{array}{l}\text { W. Arulampalam } \\
\text { A. L. Booth } \\
\text { M. L. Bryan }\end{array}$ & Training in Europe & 5 & $11 / 03$ \\
\hline 934 & $\begin{array}{l}\text { M. Piva } \\
\text { E. Santarelli } \\
\text { M. Vivarelli }\end{array}$ & $\begin{array}{l}\text { The Skill Bias Effect of Technological and } \\
\text { Organisational Change: Evidence and Policy } \\
\text { Implications }\end{array}$ & 5 & $11 / 03$ \\
\hline 935 & T. J. Dohmen & $\begin{array}{l}\text { Performance, Seniority and Wages: Formal } \\
\text { Salary Systems and Individual Earnings Profiles }\end{array}$ & 1 & $11 / 03$ \\
\hline 936 & $\begin{array}{l}\text { M. K. Jones } \\
\text { P. L. Latreille } \\
\text { P. J. Sloane }\end{array}$ & Disability, Gender and the Labour Market & 3 & $11 / 03$ \\
\hline 937 & $\begin{array}{l}\text { W. Eggert } \\
\text { L. Goerke }\end{array}$ & $\begin{array}{l}\text { Fiscal Policy, Economic Integration and } \\
\text { Unemployment }\end{array}$ & 2 & $11 / 03$ \\
\hline 938 & $\begin{array}{l}\text { D. Del Boca } \\
\text { A. Venturini }\end{array}$ & Italian Migration & 1 & $11 / 03$ \\
\hline 939 & E. Toulemonde & $\begin{array}{l}\text { Acquisition of Skills, Education Subsidies, and } \\
\text { Agglomeration of Firms }\end{array}$ & 2 & $11 / 03$ \\
\hline 940 & $\begin{array}{l}\text { A. Constant } \\
\text { Y. Shachmurove } \\
\text { K. F. Zimmermann }\end{array}$ & $\begin{array}{l}\text { What Makes an Entrepreneur and Does It Pay? } \\
\text { Native Men, Turks, and Other Migrants in } \\
\text { Germany }\end{array}$ & 1 & $11 / 03$ \\
\hline 941 & $\begin{array}{l}\text { R. V. Burkhauser } \\
\text { J. S. Butler } \\
\text { G. Gumus }\end{array}$ & $\begin{array}{l}\text { Option Value and Dynamic Programming Model } \\
\text { Estimates of Social Security Disability Insurance } \\
\text { Application Timing }\end{array}$ & 6 & $11 / 03$ \\
\hline 942 & $\begin{array}{l}\text { R. V. Burkhauser } \\
\text { J. S. Butler } \\
\text { G. Gumus }\end{array}$ & $\begin{array}{l}\text { Dynamic Modeling of the SSDI Application } \\
\text { Timing Decision: The Importance of Policy } \\
\text { Variables }\end{array}$ & 6 & $11 / 03$ \\
\hline 943 & $\begin{array}{l}\text { J. T. Addison } \\
\text { P. Teixeira }\end{array}$ & $\begin{array}{l}\text { What Have We Learned About the Employment } \\
\text { Effects of Severance Pay? Further Iterations of } \\
\text { Lazear et al. }\end{array}$ & 3 & $11 / 03$ \\
\hline
\end{tabular}

An updated list of IZA Discussion Papers is available on the center's homepage www.iza.org. 